\title{
BEZERÉDI IMRE
}

\section{Esetelemzés $^{1}$}

Jelenleg a Bács-Kiskun Megyei Rendőr-főkapitánysághoz tartozó Kunszentmiklósi Rendőrkapitányságon teljesítek szolgálatot a rendészeti osztályon, a körzeti megbízotti alosztály vezetőjeként. A rendőrkapitányság a „kis” kapitányságok táborát erősíti, amit korántsem a terület kiváló közbiztonsága, sokkal inkább a létszám- és a rendőrsürüség indokol. A kapitányságvezetőnek, ellentétben a kiemelt kapitányságokkal, nincs közvetlen helyettese, alárendeltségében osztályvezetők dolgoznak. A Kunszentmiklósi Rendőrkapitányságon két ilyen státus van, a rendészeti és a bünügyi osztályvezető. A bünügyi osztály három alegysége a nyomozó alosztály, a vizsgálati alosztály és a bünügyi technikai csoport. A rendészeti osztály ugyancsak jól elkülönülö alegységekre oszlik: a körzeti megbízotti alosztály, az ör- és járörszolgálati alosztály, a közlekedésrendészeti alosztály, az igazgatásrendészeti alosztály és a Szabadszállási Rendőrőrs alosztály jogállással. További két külön jogállású csoport funkcionál a rendészeti osztály közvetlen alárendeltségében: a szabálysértési előkészítő csoport és a szolgálatirányító parancsnoki csoport. E két alegység müködéséért ugyancsak a rendészeti osztályvezető a felelős azzal, hogy tevékenységük felügyeletében részt vesz a körzeti megbízotti alosztályvezető és az őrsparancsnok is.

\section{Az esemény}

Bács-Kiskun megyei rendőrként emlékeztetek a médiában is nagy visszhangot kiváltó, lassan három éve történt eseményre. A Kecskeméti Rendőrkapitányság alá tartozó Tiszakécskei Rendőrőrsön teljesítettem szolgálatot bünügyi nyomozóként, amikor egy délután a kollégáim említették, hogy baj történt a megye egyik rendőrörsén. Egyszerüen addig nem is hittük a hallottakat, amíg magunk utána nem jártunk. Amikor parancsnok lettem, és közvetlenebb kapcsolatom volt a területi szakirányítással, megkíséreltem e rendkí-

\footnotetext{
1 A szerző a Nemzeti Közszolgálati Egyetem Rendészettudományi Kar MA szakos levelező hallgatója. A cikk alapja a Rendészeti szervek müködésének jogi alapjai elnevezésü tantárgyból teljesített és jelesre értékelt kollokviumi dolgozat.
} 
vüli esemény parancsnoki kivizsgálásának tanulmányozását, de a hozzáférést elutasították. A megyei szakirányítás annyit árulhatott el, hogy a parancsnoki kivizsgálás közel háromszáz oldal lett. Az időközben elkészült vádirat szerint az első- és másodrendü vádlottak, két rendőr, B. Viktor és $B$. Csongor 2013. április 8-án 17 óra körül Orgoványon intézkedtek a 47 éves Bara Józseffel szemben, mert egy férfi azt jelentette, hogy lopott tőle. Hátrabilincselték a kezét, és az őrsre szállították. Valamivel 18 óra előtt érkeztek meg, a férfit leültették egy székre, majd csukott ajtó mögött vallatni kezdték. A két vádlott mintegy két órán át felváltva és együtt is nagy erővel bántalmazta a sértettet azért, hogy vallomást tegyen és elismerje a büncselekményt. Többször ököllel megütötték a mellkasát, Bara pedig az ütések következtében a széken ülve hanyatt esett, hátrabilincselt keze a szék és a teste alá szorult. A vádlottak ezután is folytatták a bántalmazást, két oldalról, többször ököllel és gumibottal ütötték a mellkasát, B. Viktor pedig az időközben hason fekvő helyzetbe került Barát gumibottal nagy erővel is folyamatosan ütötte. Bara József végül rosszul lett, majd este nyolc körül eszméletét vesztette. A vádlottak ekkor mentőt hívtak, és megpróbálták újraéleszteni. Bara József azonban meghalt, a helyszínre érkező mentőtiszt már nem tudott segíteni rajta.

A vádirat szerint Bara a kitartó bántalmazás miatt a fején és testszerte számos külső sérülést, súlyosabb, életveszélyes sérülésként tüdőzúzódást, szegycsonttörést és sorozatos bordatöréseket szenvedett. Halálát a terjedelmes zsírszövet-roncsolódás következtében kialakult zsírembólia miatt beálló fulladás okozta. A helyiek szerint Bara problémás ember volt, ivott, mindenféle munkát elvállalt, de a kisebb lopásoktól sem riadt vissza. A rendőröket egy ismerőse hívta ki, hogy intézkedjenek Bara ellen, aki a feljelentő szerint visszaélt a bizalmával: nemcsak a stílfürészét, de a németektől kapott sonkáját is ellopta. B. Viktor vallomásában azt mondta, hogy a szabályokat betartva jártak el a sértettel. „Egy eröszakos emberrel szemben kellett fellépniük, ezért szükség volt az elöírásoknak megfelelö kényszerintézkedések arányos alkalmazására. A gyanúsitott élete legnagyobb tragédiájaként beszélt a halálesetröl, aláhúzva, hogy kollégájával együtt mintegy fél órán át próbálták újraéleszteni a lopás gyanújával elfogott férfit" - nyilatkozta nem sokkal a letartóztatása után az ügyvédje. Az ügyben az országos rendőrfőkapitány is megszólalt. „Magyarország rendőrsége jogállami keretek között müködik. Senki, így a közhatalmat gyakorló rendör sem állhat a törvények felett" - olvasható az ORFK áprilisban kiadott közleményében. A kommüniké kitér arra is: az országos rendörfökapitány tényfeltáró vizsgálatot folytat az ügyben, és ,„az Izsáki Rendörörsön történtek nem ismétlödhetnek meg”. A verésröl 
végül egy háromszáz oldalas jelentés készült, amelyet elküldtek Pintér Sándor belügyminiszternek. ${ }^{2}$

\section{Vélt okok}

A helyiek szerint a rendőrök szigorúak voltak. Bár az egyikükről korábban nem feltételezték volna, a másikról már tudták, hogy amikor „kellett”, odacsapott, őt a helyiek szerint keményebb fából faragták. Az ügyészség Bara József megverésén kívül több másik, 2013 januárjában, februárjában és márciusában elkövetett büncselekmény miatt is vádat emelt B. Viktor és B. Csongor, valamint több más rendőr ellen. Az első-, a másod- és a harmadrendü vádlottak máskor is vertek már meg gyanúsítottakat vallatás közben, a vádirat szerint négy férfit bántalmaztak azért, hogy vallomást tegyenek. Ezek az emberek a bántalmazások miatt könnyebb, nyolc napon belül gyógyuló sérüléseket szenvedtek. A bünügy negyedrendủ vádlottja ellen azért emelt vádat az ügyészség, mert az egyik sértett bántalmazásánál jelen volt, de nem lépett fel az első- és másodrendủ vádlottak jogellenes, erőszakos magatartása ellen. A vádlottakat - akik közül az első- és a másodrendü előzetes letartóztatásban, míg a harmad- és negyedrendủ szabadlábon van - a Kecskeméti Nyomozó Ügyészség a halált okozó testi sértés büntettén kívül kényszervallatás, jogellenes fogva tartás, hivatalos eljárásban elkövetett bántalmazás, hivatalos személyként elkövetett közokirat-hamisítás büntetteivel, továbbá könnyü testi sértés vétségével is vádolja.

\section{Felsőbb vezetői intézkedések}

A belügyminiszter nem menesztette az országos rendőrfőkapitányt - derül ki abból a közleményből, amelyet az Országos Rendőr-főkapitányság kommunikációs szolgálata közölt a Police.hu oldalon. Pintér Sándor - akit az országos fökapitány folyamatosan tájékoztatott az eseményekről - tudomásul vette Papp Károly jelentését az izsáki haláleset ügyében megtett intézkedésekről, és bizalmáról biztosította az ORFK vezetőjét. ,, Magyarország rendőrsége jogállami keretek között müködik. Senki, igy a közhatalmat gyakorló rendör sem állhat a tör-

2 Albert Ákos: A bíróságon magyarázkodhatnak az izsáki rendőrök. Origo.hu, 2013. december 17. http://www.origo.hu/itthon/20131216-kezdodik-az-izsaki-kenyszervallato-rendorok-pere.html 
vények felett" - olvasható a közleményben, amely szerint Papp Károly vezérőrnagy, aki 2013. február 4-től látja el az országos rendőrfőkapitányi beosztást, beiktatásakor és utána számos esetben megfogalmazta ezt a követelményt, külön hangsúlyozta az emberi jogok tiszteletben tartását és betartását valamennyi rendőri intézkedés során. Az Izsáki Rendőrőrs parancsnokát azonban rögtön felmentették a beosztásából, továbbá a Kiskőrösi Rendőrkapitányság vezetője is rendelkezési állományba került. Az Izsáki Rendőrőrsön a központi szerv ellenőrzési szolgálata a megyei szakirányítással közösen minden személyes szabadságot korlátozó intézkedésről szóló jelentést górcső alá vett, ennek kapcsán további két kolléga ellen indult büntetőeljárás. Ez után a Bács-Kiskun Megyei Rendőr-fökapitányság valamennyi szervezeti egységénél ellenőrizték a személyes szabadságot korlátozó intézkedésekről készült jelentéseket. Bár az ügyben még nem született semmilyen tanulmány, az előállított és személyes szabadságukban korlátozott személyekkel szembeni intézkedések dokumentálására a megyei rendőrfőkapitány további normákat alkotott, a korábbi szabályzatokban foglalt végrehajtást és azok dokumentálását az ellenőrzések megnövekedésével kiemelten kezeli. Az Izsáki Rendőrőrsön ez után kezdetét vette féltucatnyi áthelyezés, amit az ott szolgálatot teljesítő rendőrök kértek. A rendőrőrs parancsnoki vezetése ideiglenes jellegü volt: helyettesi feladatokra senki nem vállalkozik.

\section{Helyzetkép}

A jelenlegi szolgálati helyem, a Kunszentmiklósi Rendőrkapitányság adottságai nagyban megegyeznek a bemutatott esemény helyszínének jellemzőivel, ezért a Szabadszállási Rendőrőrs területére kívánom azt gondolatban átültetni, ami bár területileg kisebb, ám mivel Izsákkal határos és lakossági kapcsolataiban koherens, ezért annak hatása jelenleg itt is érezhetö.

A Kunszentmiklósi Rendőrkapitányság illetékességi területén kilenc település található, három város és hat falu. A városok közül a székhelyként szolgáló Kunszentmiklós tízezer fö feletti lakosú, Dunavecse négyezer körüli, valamint Szabadszállás város és annak agglomerációja közel hatezer-ötszáz fös populációt tudhat magáénak. A rendőrkapitányság teljes személyi állománya 87, ebből 73 hivatásos rendőr. Az állománytábla szerint a Szabadszállási Rendőrőrsön öt megüresedett státus betöltetlen, ez a kapitányság tipizálásának következménye, hiszen a kényszervallatás előtt is létszámproblémákkal küszködött a kapitányság, a rendőrorrsön most tizennégyen dolgoznak, közülük, egy örsparancsnok, négy járőr, és négy körzeti megbízott. Az őrsparancsnok ugyancsak ideiglenes, 
helyettese nincs. Pontos, kitartó, serény munkavégzés jellemzi. A nyolc beosztott hónapokig nehezen fogadta el, mivel a korábbi őrsparancsnoktól eltérő elvek szerint irányít. Az örsparancsnok munkáját nehezíti továbbá, hogy a kényszervallatás után a rendőrség visszavonulót fújt, hivatkozva a helyi lakosok támadására és a létszámhiányra, a megmaradt nyolc rendőr pusztán reaktív jelleggel a bejelentésekre, küldésekre vonult, saját kezdeményezésű eljárással nem léptek fel. A helyi lakosokon túl ezt az átutazó bünöző csoportok is megérezték, és elöszeretettel választották e területet a cselekményeikhez.

Fontos leszögezni, hogy a következőkben írt célkitűzések csakis együttesen, egymással párhuzamosan hajthatók végre, azonban azok szubjektív kifejtése célszerü.

\section{Személyügyi intézkedések}

Állománytábla szerint a rendőrkapitányság feltöltöttsége 93 százalék a hivatásos végrehajtó állomány vonatkozásában, ez jónak mondható. Kifejezetten a rendőrőrs illetékessége tekintetében ez az arány már csak 64 százalék. A rendőrőrsön legelőször azt szükséges megvizsgálni, hogy a jelenleg ott szolgálatot teljesítő állomány tagjai képesek-e megbirkózni a közeljövőben rájuk nehezedő nyomással, szakmailag megfelelően képzettek-e, pszichikumuk, mentális állapotuk alkalmassá teszi-e őket a feladatuk elvégzésére. Ha igen, akkor gondoskodni kell a további három járőr és egy körzeti megbízotti státus betöltéséről. Elsősorban az örsparancsnoknak és a rendészeti osztályvezetőnek kell lehetővé tenni a pótlást, ehhez javasolt ajánlatot tenni a rendőrkapitányságon dolgozók között azoknak, akiknek kellő szakmai tapasztalatuk, képességük és legföképp motivációjuk van. Figyelembe kell venni azonban, hogy az újonnan kinevezett beosztott korábbi munkaköre ugyancsak betölthető legyen. Ha a helyzet helyi szinten nem megoldható, pályázatot kell kiírni, de ha az ügy így sem oldódik meg, rövid ideig érdemes megbízni e munkakörök betöltésével a helyi hivatásosok közül az erre vállalkozókat.

\section{A közbiztonság helyreállítása, a közösségi rendőri szerep kialakítása}

A helyi szinten jelenlévő jogsértések arra serkentik a lakosokat, hogy elzárják, elszigeteljék magukat a rendőrségtől. Nagyon fontos egy új irány kiala- 
kítása, vagyis a közösségi rendőri szerep megteremtése. Az általános feladatokat ellátó rendőrség a tevékenységét az alaptörvény, jogszabályok, továbbá belső szabályzók (normák, utasítások) szerint végzi. Finszter Géza szerint „,a rendészet a modern államban az a közigazgatási tevékenység, amelynek társadalmi rendeltetése a jogellenes emberi magatartásokból keletkezö veszélyek elháritása". ${ }^{3}$

A Concha Gyözö által már 1901-ben tárgyalt őrködő mechanizmus csakúgy, mint a Finszter Géza által definiált közbiztonság a lakossággal létrehozott „kooperációs termék”. „A Rendörség a feladatait eredményesen akkor tudja teljesiteni, ha a munkájához igénybe veszi a szükebb és tágabb közösség, a társadalom segitségét. Magyarországon az 1990.-ben bekövetkezett társadalmi változások, a demokratikus átalakulás még inkább elötérbe hozta a Rendörség ilyen irányú feladatokat [...] A helyi közbiztonság javitásában kitüntetett szerepe van a rendörségnek, amelynek a közbiztonságot fenyegetö veszélyek azonositása, elháritása érdekében állandó kapcsolatban kell lennie a közösséggel. A már megvalósult konkrét büncselekményekröl szerzett tapasztalataikat el kell juttatni az érintettekhez és az adott veszélyeztetett közösséghez is. Ezek a tapasztalatok akkor hasznosulnak a bünmegelözésben, ha a bünözésröl szerzett ismereteiket megosztják a büncselekményi okok hatását csökkenteni, a bünalkalmakat megszüntetni, az áldozattá válást megelözni képes állami, civil és szakmai szervezetekkel, intézményekkel, egyházakkal. A rendőrök mellett a polgárőrök, a közterület-felügyelök, vagyonörök, magánnyomozók, a kisebbségi önkormányzatok, természetvédelmi örök, a védönök, a pedagógusok, a házi-és szakorvosok, a gyermekvédelem szakemberei, a szociális szakemberek, a családsegitök, a szociális és egészségügyi ellátó rendszerben dolgozók, az alkohol- és drogmegelözésben és kezelésben résztvevők az alulról épitkezö bünmegelözés legfontosabb szereplöi. "“

Ebben a helyzetben a rendörségnek kiemelten oda kell figyelnie a lakosságra, vissza kell szerezni a bizalmukat, hogy a továbbiakban együtt dolgozhassunk velük. Ehhez mindenképpen szükséges beállítani megfelelő érzékenységü, lehetőleg helyi lakosokból álló járőrpárosokat. A közterületen szolgálatot teljesítők létszámát szükség esetén napszakonként más területröl

\footnotetext{
3 Finszter Géza: A rendészet átalakulásának húsz esztendeje (1988-2008). In: Sándor Péter - Stumpf Anna - Vass László (szerk.): Magyarország politikai évhuszadkönyve. A magyar demokrácia kormányzati rendszere (1988-2008). Demokráciakutatások Magyar Központja Közhasznú Alapítvány, Budapest, 2009

4 Csomós István: Társadalmi ismeretek. Nemzeti Szakképzési és Felnőttképzési Intézet, Budapest, 2007, 11-12 o.
} 
egy-egy óra időtartamban kell megoldani. A közterületi állomány figyelmét fel kell hívni az intézkedések kulturált, következetes végrehajtására. Az osztályvezető követelje meg a rendőrőrs parancsnokától a járőrök útirányának helyzettudatos, tervszerü elkészítését. Kerülni kell a razziajellegü akciók gyakori végrehajtását, az országos rendőrfőkapitány által polgárpukkasztónak nevezett megnyilvánulásokat. A rendőrjárőr elérhetősége - akárcsak a körzeti megbízotté - közismert kell hogy legyen. A körzeti megbízotti és a járőrszolgálatot úgy kell megszervezni, hogy minél közvetlenebb kapcsolat alakuljon ki köztük és a lakosság között. Fokozni kell a gyalogos rendőri jelenlétet, a gyalogos járőri szolgálatok számát és arányát a jó kapcsolat érdekében. „A közvélemény-kutatási eredmények is azt igazolták, hogy amióta kiszállitották a járöröket a járörautókból, sokkal kevesebb kritika érkezik lakosság részéröl a rendörség reagálási sebességére, a problémaérzékenységre. " A bünügyi szolgálat esetében ugyancsak el kell érni, hogy a bejelentő bizalommal forduljon a rendőrséghez, egy-egy eljárás során az előadó személyesen hallgassa meg az érintett lakosokat, kevésbé megterhelővé téve a büntetőeljárási procedúrát. A rendőrség helyi szintü segítségnyújtása csak így lehetséges. A rendőrkapitányság vezetőjeként napi kapcsolatban kell állni az említett szervek vezetőjével, a kérésükre azonnal reagálni kell, ezzel érzékeltetni, mennyire fontos a szerepük. A helyi lapokban, térségi televízióban bünmegelözési tanácsadással egybekötött rendőrségi tájékoztatót kell közvetíteni, amelyekben be lehet számolni az elért sikerekről. A cikkekben, riportokban ki kell emelni az állampolgárok részvételének fontosságát. A rendőrség proaktív szerepét erősítve egyes prevenciós programok végrehajtására (DADA, iskolarendőr) bűnmegelőzési tiszteket kell delegálni. Mivel „,szükség van azonban olyan, a társadalmat ösztönzö és mozgósitó programok, technikák intézményesitésére is, amelyek a nagy-és kis közösségek, az intézmények, a gazdasági szereplök és az állampolgárok önvédelmi képességét, bünözéssel szembeni védettségét fokozzák", ezért további bün- és baleset-megelőzési programok, rendezvények kellenek. A bünügyi szakterület az egyes rendezvényeken bünmegelőzési tanácsadással, rendészeti terület képviselői bemutatók (alaki, intézkedés, kutyás), a közlekedésrendészeti terület pedig a helyi iskolák tanulóinak versenyekre való felkészítése, kerékpáros KRESZ-park, és más hasznos programok megtartásával járulnak hozzá a lakosság ilyen jellegü igényeinek kielégítéséhez. Fontos feléleszteni a rendőrkapitányság együttműködését a kisebbségi önkormányzatokkal is, feladat-

5 Uo. 12 o.

6 Uo. 
tervet készíteni az együttmüködés jegyében megvalósítandó feladatokról. Lakossági fórumokon be kell számolni a rendőrség eddigi tevékenységéről, érzékenyen kell fogadni a visszajelzéseket és a kritikákat. A stratégiai partnerekkel, a helyi szervek vezetőivel közbiztonsági fórumot kell tartani, ezen elhangozhatnak eddig nem ismert problémák és jelzések.

\section{A rend megszilárdítása}

A cikk elején említett rendkívüli esemény utáni időszakban bevezetett intézkedések elősegítették a lakossággal való összefogást, az itt élők szubjektív biztonságérzetének javítását. A nehéz időszakban kiemelkedő teljesítményt nyújtó állományt az elért eredményről történő tájékoztatáson felül dicséretben és lehetőség szerint jutalomban is kell részesíteni. A korábban szervezett együttmüködéseket rendszeresen ápolni kell. A lakosságot érintő programokat erősíteni kell, továbbá fokozni szükséges a toborzó tevékenységet is a rendőrség vagy a polgárőrség kötelékébe.

\section{Összegzés}

Az esetelemzéssel annak igazolása volt a célom, hogy a rendészetelméleti ismeretek a gyakorlatban hasznosíthatók. Az utca rendőre a lakosság mindennapi problémáival úgy találkozik, hogy azokra sokszor halasztást nem türö, önálló választ kell adnia. Ha a szakmai vezetés módszerei nélkülözik a kooperatív elemeket, akkor a parancsnoki utasítás felelősségtől mentes, üres végrehajtási procedúrává silányíthatja a valós élethelyzetet. Ez hosszabb távon jelentősen ronthatja a vezető irányító munkájának eredményességét is. A közösségi rendőrség kialakítása egyfajta biztonságot nyújthat a rendőrségnek azáltal, hogy stratégiai partnerként a közösség akarata irányába mozdítja az időközben egyre nyitottabbá váló rendőrséget, a döntések és azok végrehajtása a társadalom színterén történik. Ez a szemlélet a rendőrség belső életére is jótékony hatású lehet.

\section{IRODALOM}

300 oldalas jelentést írtak az izsáki agyonverésről. Origo.hu, 2013. május 24. http://www.origo.hu/itthon/20130524-300-oldalas-jelentest-irtak-az-izsakiagyonveresrol.html 
Albert Ákos: A bíróságon magyarázkodhatnak az izsáki rendőrök. Origo.hu, 2013. december 17. http://www.origo.hu/itthon/20131216-kezdodik-az-izsaki-kenyszervallato-rendorok-pere.html Csomós István: Társadalmi ismeretek. Nemzeti Szakképzési és Felnőttképzési Intézet, Budapest, 2007

Finszter Géza: A rendészet átalakulásának húsz esztendeje (1988-2008). In: Sándor Péter Stumpf Anna - Vass László (szerk.): Magyarország politikai évhuszadkönyve. A magyar demokrácia kormányzati rendszere (1988-2008). Demokráciakutatások Magyar Központja Közhasznú Alapítvány, Budapest, 2009

Krémer Ferenc: Szociológiai alapismeretek. Kézikönyv rendvédelmi hallgatók számára. Rejtjel Kiadó, Budapest, 2003

Krémer Ferenc - Molnár Katalin - Szakács Gábor - Valcsicsák Imre: A rendészeti foglalkozási kultúra átalakítása - stratégiai koncepció. Rendészeti Szemle, különszám, 2010. március

Krémer Ferenc: Rossz döntések kora. Rendészetpolitikai tévelygések a rendszerváltás első húsz évében. Napvilág Kiadó, Budapest, 2010

Sárközi Ferenc: Közrendvédelmi ismeretek. Tankönyv. Pest Megyei Rendőrfökapitányság, 1999 